\title{
Radioanatomical Features of the Sphenoid Sinus in the Ivorian Population
}

Maman You Espérance BROALET *1, Dié Doweh Renaud 2, Djibril Ouattara ${ }^{3}$, Jean-Baptiste Kéké ${ }^{4}$, Mohamed Koné ${ }^{5}$.

${ }^{* 1}$ Normal Anatomy and Health Simulation Laboratory, UFR-SM, Alassane Ouattara University Bouaké.

${ }^{2}$ Normal Anatomy and Health Simulation Laboratory, UFR-SM, Alassane Ouattara University Bouaké / Côte d'Ivoire.

${ }^{3}$ Laboratory of Normal Anatomy, Experimental Surgery and Biomechanics, UFRSM Abidjan, Félix Houphouët Boigny Universty/ Côte d'Ivoire.

${ }^{4}$ Department of Neurosurgery, Bouaké University Hospital Center / Côte d'Ivoire.

${ }^{5}$ Department of Neurosurgery, Yopougon University Hospital Center / Côte d'Ivoire.

\section{ABSTRACT}

Background and purpose: The sphenoid sinus is characterized by the frequency of anatomical variants that cause operative difficulties and complications during the transphenoidal approach. These variants involve the geographic factor and the type of skin phenotype. Most of the studies have been carried out on European, North African and Asian populations. Some studies have been found in sub-Saharan Africa but not in Côte $d^{\prime}$ Ivoire. The aim was to determine, from CT data, the anatomical characteristics of the sphenoid sinus in the Ivorian population.

Methods: Cranioencephalic computed tomography images of 100 patients (80 men and 20 women aged 16 to 71) were used for the study. These were patients who presented with head trauma without injury to the base of the skull. Were studied the anatomical characteristics of the sphenoid sinus.

Results: The type of pneumatization was sellar in $58 \%$ sinuses, pre sellar in $41 \%$ and conchal in $1 \%$ of cases. The presellar type predominated in women $(60 \%)$ and the sellar type in men (65.5\%). Extensions were present in $66.34 \%$ of cases, more frequent in men (70\%), in the sellar type $(79.31 \%)$, and in the anterior clinoid process (46.20\%). The procidence of vasculo-nervous structures was more frequent in men (52.62\%) and in the sellar type $(62.07 \%)$, the procidence of the internal carotid artery was bilateral in $30.69 \%$ of sinuses, that of the optic nerve was mainly unilateral left $(07.92 \%)$ more frequent in women $(10 \%)$ and in the sellaire type (09.43\%). Dehiscence was present in $15 \%$ of cases. Dominance was straight in $63.64 \%$ of the sinuses. The Onodi cell was present in $65 \%$ of sinuses. The ostium was bilateral in (45\%) of the sinuses.

Conclusion: The Ivorian sphenoid sinus is highly pneumatized, facilitating access to the surgeon; the sellar type is the most frequent. On the other hand, the frequency of procidence and dehiscence of vasculo-nervous elements increases the risk of surgical complications. Differences between genders and between types of pneumatization should be considered in sphenoid sinus procedures.

KEY WORDS: Sphenoid Sinus, Computed Tomography, Anatomic Variation, Ivorian

Corresponding Author: Maman You Espérance BROALET, Associate Professor and Head of the Normal Anatomy and Health Simulation laboratory, alassane Ouattara University, Côte d'Ivoire. Phone : +2250707079041 E-Mail: broaletyou@yahoo.fr

Access this Article online

\section{Quick Response code}

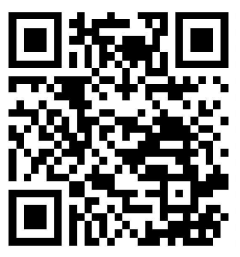

DOI: $10.16965 /$ ijar.2021.187

Journal Information

\section{International Journal of Anatomy and Research}

ISSN (E) 2321-4287 | ISSN (P) 2321-8967

https://www.ijmhr.org/ijar.htm

DOI-Prefix: https://dx.doi.org/10.16965/ijar

(cc) $\mathrm{BT}-\mathrm{No}-\mathrm{si}$

Article Information

Received: 09 Nov 2021

Peer Review: 09 Nov 2021
Accepted: 04 Jan 2022

Published (O): 05 Mar 2022

Published (P): 05 Mar 2022 


\section{INTRODUCTION}

The sphenoid sinus is characterized by the frequency of anatomical variations and by its close relationship with important anatomical structures including the internal carotid artery, the optic nerve and the cavernous sinus. They are the cause of operational difficulties during the transphenoidal approach. The type of pneumatization and these vasculo-nervous relationships determine the risk of complications occurring during surgery. Benchmark technique for pituitary surgery since the advent of the operating microscope in 1960, the transphenoidal approach has been revolutionized and has become essential since the development of endoscopy, which has improved the results of surgery $[1,2,3,4,5]$.

The anatomy of the sphenoid sinus is extremely complex, but essential to know for the surgeon. Medical imaging, especially computed tomography, is of undeniable help in studying this anatomy [4]. The anatomical variants involve the geographic factor and the type of skin phenotype. Many studies are found in Europe, Asia, America, north Africa $[6,7,8,9,10,11]$; a few in sub-Saharan Africa $[12,13,14]$, but no study was found in Côte d'Ivoire.

The aim of our study was to determine the radioanatomical characteristics of the sphenoid sinus in the Ivorian population from scannographic data at the University Hospital Center of Bouaké in center of the country, in order to define the operative risk during 'transphenoidal approach.

\section{METHODS}

This was a retrospective study with descriptive and analytical purposes. The CT images of 100 patients ( 80 men and 20 women) were collected at the neurosurgery department of the Bouaké University Hospital. The CT scan had been ordered for a head trauma. Computed tomography with lesion of the base of the skull was excluded. The patients were hospitalized between February 28th, 2013 and March 13th, 2017. Their ages ranged from 16 to 71 years with an average of 29.5 years. The average age of women was 25.50 years and the average age of men was 31.5 years. The three-dimensional images were obtained by reconstruction of the axial images using a section thickness equal to $(0.4 \mathrm{~mm})$.

The type of pneumatization, according to the classification of Hammer and Radberg, 1961 [15], its different variants and modalities of extensions, the existence or not of an Onodi cell, the characteristics of the septum, the type of reports of the vasculo- nerve scans of one hundred cranioencephalic bone window scans showing the sphenoid sinus were studied. Epi info 7 software was used for the analysis of the data collected.

As in most retrospective studies, we worked with files that did not provide answers to all of the items in our questionnaire; none of the 100 files studied specified the height and weight of the patients.

\section{RESULTS}

Pneumatization: The three types according to Hammer and Radberg (1961) [15] have been found (Figure 1).

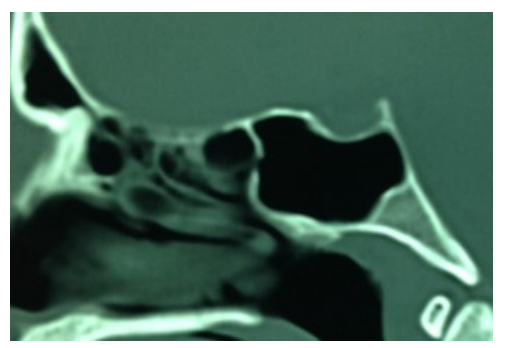

a. Sellar Type (58\%)

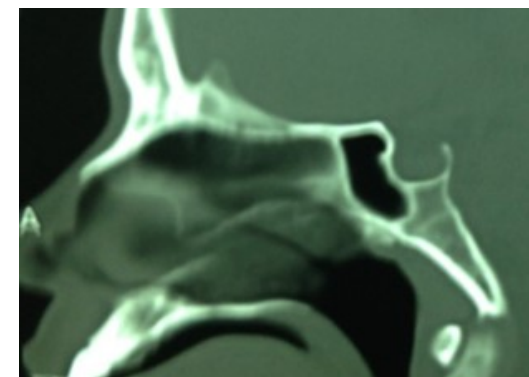

b. Presellar type (41\%)

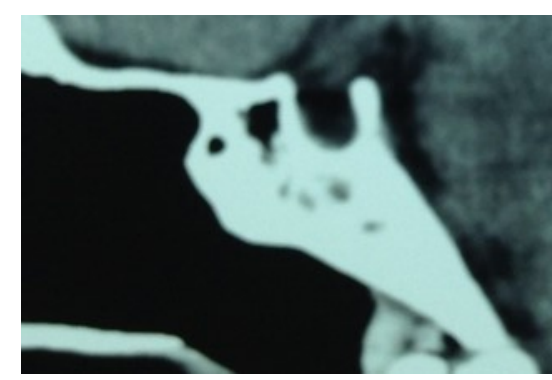

c. Conchal type (1\%)

Fig. 1: Distribution of the type of pneumatization according to the Hammer and Radberg classification. 
In women, the sellar type was found in 8 cases $(40 \%)$ and the presellar type in 12 cases $(60 \%)$. In men, the sellar type was found in 50 cases (62.50) and the presellar type in 29 cases (36.25\%). The conchal type was found in a man (01.25\%) (Figure 2).

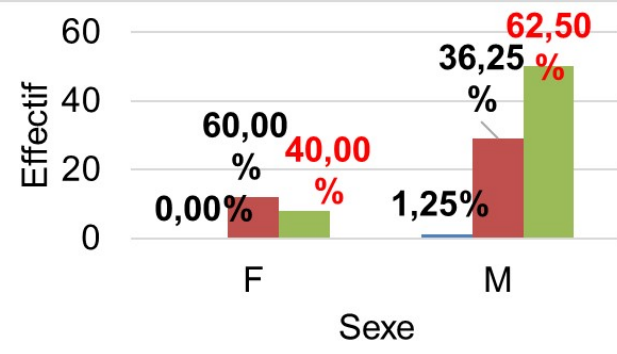

- Conchal Présellaire Sellaire

Fig. 2: Distribution of the type of pneumatization by sex.

Extension: An extension was found in $67 \%$ of cases. It was present in 11 (55\%) women and $56(70 \%)$ men. It was found for the sellar type in 46 cases (79.31\%) out of 58 , and for the pre sellar type in 21 cases (51.22\%) out of 41 . This extension was done in the anterior clinoid process ( 31 cases or $46.27 \%$ ), the large wings (27 cases or $40.30 \%$ ), anteriorly (22 cases or $32.84 \%$ ), in the dorsum sellae (15 cases or $22.39 \%$ ), the basi occiput (12 cases or $17.91 \%$ ), small wings ( 8 cases or $11.94 \%$ ), the pterygoid process ( 8 cases or $11.94 \%$ ) (Figure 3 ). There was no extension in the planum.
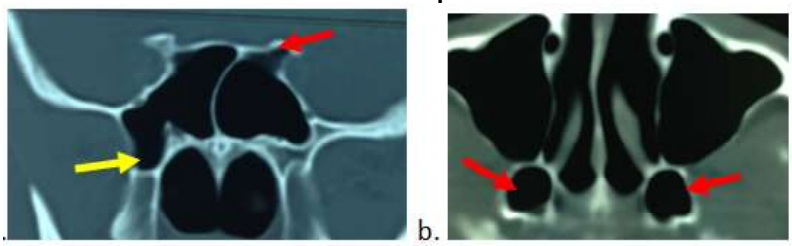

Fig. 3: extensions. a. Frontal section: in the anterior clinoid process (red arrow); in the pterygoid process (yellow arrow). b. Horizontal section: in both pterygoid processes

Septation and dominance: The septum was present in $98 \%$ of cases, in 19 women (95\%) and 79 men (98.75\%); single in $64 \%$ of cases, multiple in $34 \%$ of cases varying from 2 to 5 with an average of 3 , with different orientations vertical $(72.45 \%)$, oblique $(23.47 \%)$ or horizontal in $(4.08 \%))$. The septum was complete in 70 sinuses (71.42\%) of the 98 sinuses, incomplete in the rest of the cases, symmetrical in 21 (21.42\%) sinuses. It was inserted into vasculo-nervous elements in $39(39.79 \%)$ of the 98 sinuses with septation (Figure 4).
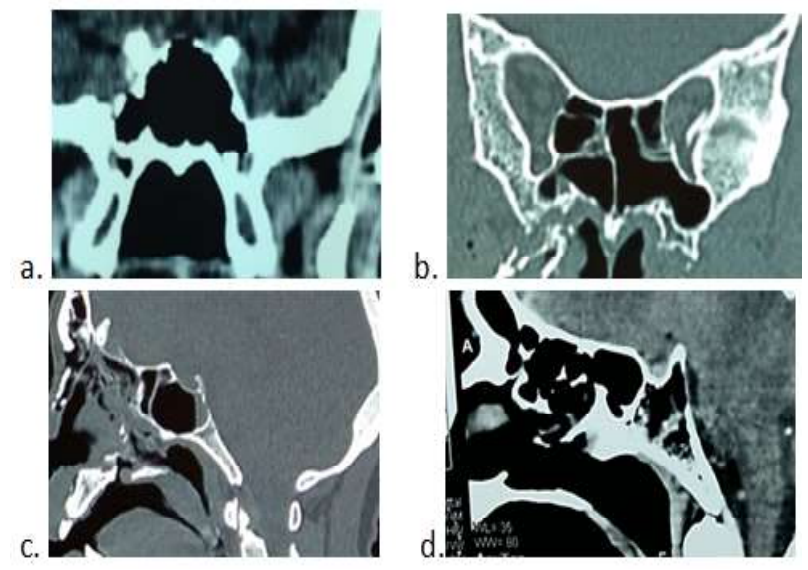

Fig. 4: Frontal sections: a. absence of septum. b. multiple septa. Sagittal sections: c. frontal septum. d. multiple frontal septa

In the pre-sellary type: the septum was present in 40 sinuses, ie $97.56 \%$. In the sellar type: the septum was present in $100.00 \%$ of cases. In the pre-sellar type the septum was unique in $24(60 \%)$ sinuses and it was multiple in 16 (40\%) sinuses while in the sellar type it was unique in $40(68.97 \%)$ sinuses and multiple in 18 (31.03\%) sinuses. In women: the septum was unique in 16 women or $80.00 \%$ of women and it was multiple in 03 or $15.00 \%$ of women. In men it was unique in 48 men or $60.00 \%$ of men and it was multiple in 30 men or $37.50 \%$ of men.

The septum insertion site was normal in 46 sinuses, i.e. $53.49 \%$ of sinuses, was on the wall of the right $\mathrm{ACl}$ in 12 (13.95\%) sinuses, on the wall of the left $\mathrm{ACl}$ in $07(08.14 \%)$ sinuses, bilaterally on the walls of the two ACls in 13 $(15.12 \%)$ sinuses, on the wall of the right optic nerve in $02(02.33 \%)$ sinuses, on the wall of the left optic nerve in $02(02.33 \%)$ sinuses, bilaterally on the walls of the two optic nerves in $01(01.16 \%)$ sinuses and finally on the floor of the sella turcica in 02 (02.33\%) sinus of the 98 sphenoid sinuses (figure 5 ).

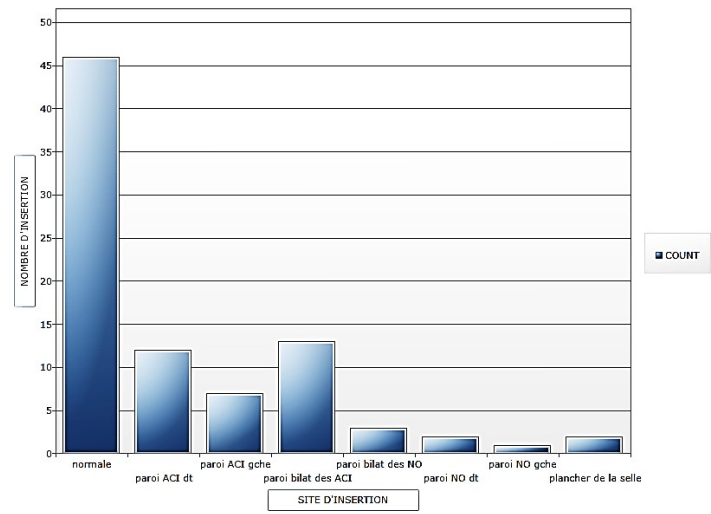

Fig. 5: Distribution of the septum insertion site. 
In the pre-sellary type: the septum was present in 40 sinuses, ie $97.56 \%$. In the sellar type: the septum was present in $100.00 \%$ of cases. In the pre-sellar type the septum was unique in $24(60 \%)$ sinuses and it was multiple in $16(40 \%)$ sinuses while in the sellar type it was unique in $40(68.97 \%)$ sinuses and multiple in 18 ( $31.03 \%$ ) sinuses. In women: the septum was unique in 16 women or $80.00 \%$ of women and it was multiple in 03 or $15.00 \%$ of women. In men it was unique in 48 men or $60.00 \%$ of men and it was multiple in 30 men or $37.50 \%$ of men.

The septum insertion site was normal in 46 sinuses, i.e. $53.49 \%$ of sinuses, was on the wall of the right $\mathrm{ACl}$ in $12(13.95 \%)$ sinuses, on the wall of the left $\mathrm{ACl}$ in 07 (08.14\%) sinuses, bilaterally on the walls of the two ACls in 13 (15.12\%) sinuses, on the wall of the right optic nerve in $02(02.33 \%)$ sinuses, on the wall of the left optic nerve in 02 (02.33\%) sinuses, bilaterally on the walls of the two optic nerves in $01(01.16 \%)$ sinuses and finally on the floor of the sella turcica in $02(02.33 \%)$ sinus of the 98 sphenoid sinuses (figure 5).

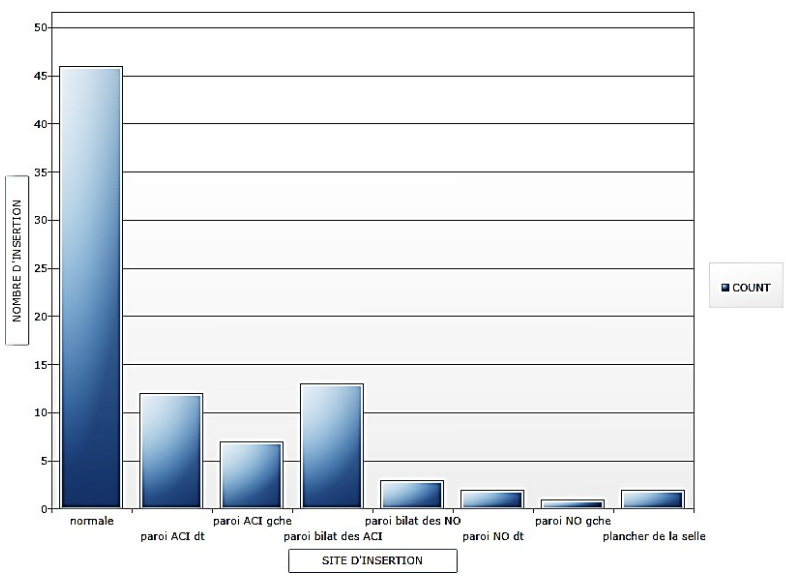

Fig. 5: Distribution of the septum insertion site.

Dominance was straight in $63 \%$ of the sinuses studied, regardless of sex and type of pneumatization. Dominance was straight in $50 \%$ of cases in women and $65.75 \%$ in men. In the pre-sellary type we had 22 right dominances or $53.65 \%$ of the type and 16 left dominances or $39.02 \%$ of the dominance. In the sellaire type we had 34 right dominances or $58.62 \%$ of the dominance in the type and 19 left dominances or $32.75 \%$ of the dominance.

Ostium : The ostium was present in all the pre sellar and sellar types studied, ie 99 (99\%) sphenoid sinuses and it was absent in the conchal (1\%) type. The position of the ostium was unilateral right in 24 sinuses, or $24.24 \%$, unilateral left in 30 sinuses, or $30 \%$, and bilateral in 45 of the 100 sphenoid sinuses studied, or $45 \%$ of these sinuses. In women, the position of the ostium was right unilateral in $06(30 \%)$ sinuses, left unilateral in $05(25 \%)$, and bilateral in $09(45 \%)$ sinuses. In men, the position was right unilateral in 18 $(22.78 \%)$ sinuses, left unilateral in 25 (31.65\%) sinuses and bilateral in 36 (45.57\%) sphenoid sinuses.

In the pre-sellar type, the position of the ostium was unilateral right in 08 (19.51\%) sinuses, unilateral left in 11 (26.83\%) sinuses and bilateral in 22 (53.66\%) of the sphenoid sinuses studied. In the sellar type: the ostium was right unilateral in $16(25.59 \%)$ sinuses, left unilateral in 19 (32.76\%) sinuses and bilateral in 23 (39.66\%) of the sinuses studied (Figure 6).

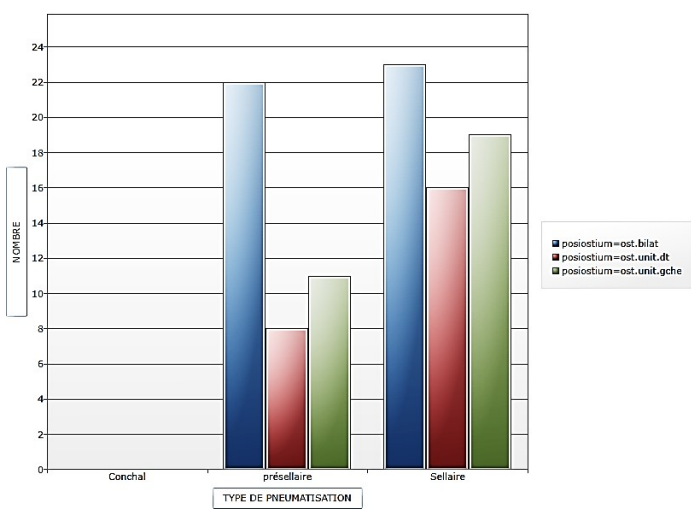

Fig. 6: distribution of the position of the ostium according to the type of pneumatization.

ONODI cells : Onodi cells were present in 65 sinuses or $65 \%$ of the sinuses studied, in 12 women or $60 \%$ of women, in 53 men or $66.25 \%$ of men. In the presellary type 24 sinuses had Onodi cells (58.54\% of the type). In the sellar type, we noted 41 (70.69\%) sinuses with Onodi cells (Figure 7).

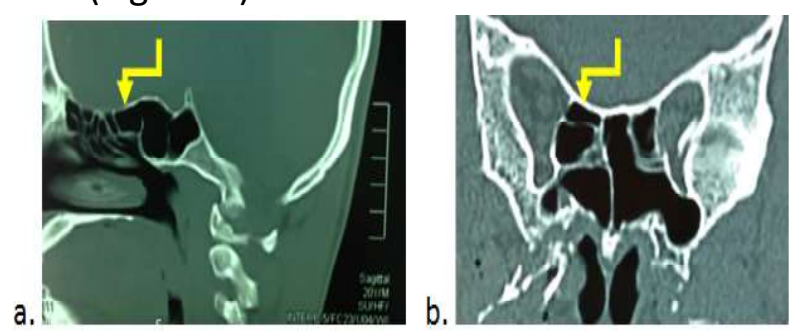

Fig. 7: Onodi cell (yellow arrow). a. Sagittal section. b. Coronal section. 


\section{Vasculo-nervous relationships}

Procidence : The procidence of vasculonervous elements was observed in $48 \%$ of cases, in the sellar type in 36 cases $(62.07 \%)$, in the pre-sellar type in 12 cases (29.27\%), in men in 40 cases (50\%), in women in 8 cases (40\%).

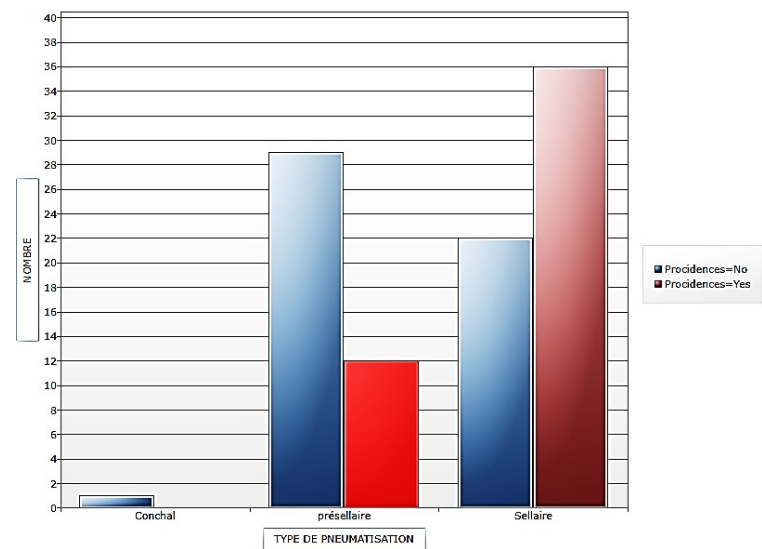

Fig. 8: Distribution of procidence according to type of pneumatization

The procidence of the internal carotid artery was observed in $38 \%$ of cases, bilateral in $31 \%$ (31 cases) (figure 9), unilateral right in 04 cases and unilateral left in 03 cases. 05 (25\%) women had bilateral internal carotid artery procidence; there was no unilateral procidence of the internal carotid arteries in the woman. In men, bilateral procidence of the internal carotid artery was found in 26 cases (32.5\%), right procidence in 04 cases and left procidence in 03 cases.

a.

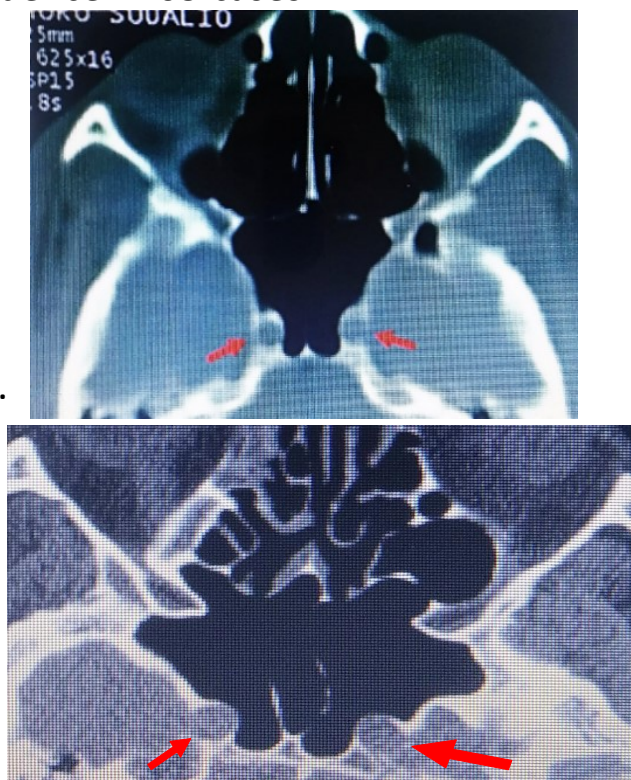

Fig. 9: procidence bilatérale de l'ACI

In the presellary type, 02 cases of unilateral procidence of the left internal carotid artery were observed, i.e. $04.87 \%$ of the pre-sellar type, and 04 cases of bilateral procidence of the internal carotid arteries, or $09.75 \%$ of the presellar type. In the sellar type, there was 01 unilateral procidence of the left internal carotid artery, i.e. $01.72 \%$ of the sellar type, and 27 bilateral procidence of the internal carotid arteries, or $46.55 \%$ of the sellar type.

The optic nerve procidence was observed in $17 \%$ of cases, right unilateral in 4 cases, left unilateral in 8 cases and bilateral in 5 cases. In women we observed 02 unilateral left procidencies of the optic nerve, ie $10.00 \%$ of women, 02 bilateral procidencies of the optic nerves, or also $10.00 \%$ of women. In males: 04 (05\%) had right unilateral optic nerve procidence, 06 (07.5\%) left unilateral optic nerve procidence, and $03(03.75 \%)$ had bilateral optic nerve procidence. In the pre-sellary type: we observed $02(04.87 \%)$ right unilateral optic nerve procidences, 03 (07.31\%) left unilateral optic nerve procidences and 02 (04.87\%) bilateral optic nerve procidences. In the sellar type, we observed 02 (03.44\%) right unilateral optic nerve procidences, 05 (08.62\%) left unilateral optic nerve procidences and 03 (05.17\%) bilateral optic nerve procidences. We also did not observe any prolapse of the vidian nerve and the maxillary nerve.

Dehiscence : 15 cases (or $15 \%$ ) presented with dehiscence of vasculo-nervous elements. according to sex, 02 women or $10 \%$ of women had it, and 13 men or $16.25 \%$ of men. According to the type of pneumatization: the dehiscence of vasculo-nervous elements was present in 06 pre-sellary types, either in $14.63 \%$ of the pre-sellar type, and in 09 sellar types or in $15.51 \%$ of the sellar-type. There was no dehiscence of vasculo-nervous elements in the conchal type.

Regarding the dehiscence of the internal carotid artery, we observed: 03 right unilateral dehiscences of the $\mathrm{ACl}, 01$ left unilateral dehiscence and 05 bilateral dehiscences of the two $\mathrm{ACl}$. In women: we observed 01 (05.00\%) unilateral dehiscence of the right internal carotid artery, as well as the left internal carotid artery and no bilateral dehiscence of the two internal carotid arteries. In humans we observed: 02 (02.50\%) unilateral dehiscences of the $\mathrm{ACl}$, no unilateral dehiscence of 
the left $\mathrm{ACl}$ and 05 (06.25\%) of both $\mathrm{ACl}$. In the presellar type, 01 (02.43\%) sphenoid sinuses had right unilateral dehiscence of the $\mathrm{ACl}$ and 02 (04.87\%) sphenoid sinuses had bilateral dehiscence.

In the sellar type: 01 ( $01.72 \%$ of the type) sphenoid sinus had unilateral dehiscence of the left $\mathrm{ACl}, 02$ (03.44\%) sinuses had unilateral dehiscence of the right $\mathrm{ACl}$ and finally 03 (05.17\%) sellar-type sphenoid sinuses had bilateral $\mathrm{ACl}$ dehiscence.

Optic nerve dehiscence was found in $6 \%$ of the sinuses studied, right unilateral in 02 cases, left unilateral in 01 cases and bilateral in 03 cases. All of these cases were found in humans. In the pre-sellary type, optic nerve dehiscence was: left unilateral in 01 ( $02.43 \%$ of type) sinus, bilateral in $02(04.87 \%)$ sinus. There was no right unilateral dehiscence of the optic nerve. In the sellar type: optic nerve dehiscence was unilateral right in 02 (03.44\%) sinuses, bilateral in $01(01.72 \%)$ sinuses. There was no unilateral left dehiscence.

\section{DISCUSSION}

The development of the paranasal sinuses, especially the sphenoid sinus, explains the many anatomical variations. Computed tomography (CT) is an excellent way to explore this area [16]. During the last decade, and due to the development of diagnostic techniques, endoscopic endonasal approaches and the latest advances in surgery have made it possible to use the sphenoid sinus as an access route to the sellar region $[10,17]$.
Type of pneumatization: The three types according to Hammer and Radberg (1961) [15] have been found. The sellary type (62\%) predominated in agreement with the literature $[4,7,8,9,18]$. On the other hand, the proportions were lower than those of most studies $[15,18]$. The sellar type predominated in men (50 out of 80 cases) [18] while the presellary type predominated in women (12 out of 20 cases). In our study, the pre-sellary type predominated in women $(60.00 \%)$, in agreement with Sevinc [9] in Turkey who found $16.6 \%$ of the pre-sellar type with a predominance of women, and unlike the study by Kajoak [18] in which the pre-sellar type was observed in 15 (15\%) cases of which 5 (8.9\%) were observed in women and $10(22.7 \%)$ in men. As in the Sudanese and Turkish populations, pre-sellar pneumatization is the second most common type of pneumatization in Ivorians, with larger proportions, and more widespread distribution among women. The sphenoid sinus is therefore more extensive in men than in women in the Ivorian population. What is the opposite in the studies of Sevinc and Kajoak [18].

The conchal type was rare (1\%) (Sévinc 0,5\%, Hamid 2\%, Banna \& Oluta 3\%, Kajoak 0\%) $[9,18,19,20]$. On the other hand Liu [21] found $10.8 \%$ of the Chinese population. As in the Turkish and Sudanese populations, the conchal type is a very rare type of pneumatization in Ivorians. (Table 1)
Table 1: Comparison of the prevalence of types of sinus pneumatization in the literature, according to the Hammer and Radberg classification [15].

\begin{tabular}{llccc}
\hline \multirow{2}{*}{ Authors } & Population & \multicolumn{3}{c}{$\begin{array}{c}\text { Prévalence of type de } \\
\text { pneumatization (\%) }\end{array}$} \\
\cline { 3 - 5 } & & Conchal & Présellar & Sellar \\
\hline Hamid and al 2008 & Egyptian & 2 & 21 & 77 \\
\hline Idowu and al 2009 & Nigerian & 0 & 5 & 89,7 \\
\hline Lu and al (2011) & Chinese & 6 & 28,5 & 65,5 \\
\hline Wiebracht and al (2014) & American & 0 & 9 & 91 \\
\hline Sévinc and al (2014) & Turkish & 0,5 & 16,6 & 83 \\
\hline Manisha and al (2014) & Indian & 2 & 14 & 84 \\
\hline Kajoak et al 2014 & Soudanese & 0 & 15 & 85 \\
\hline Bicaba (2017) & Burkinabe & 0,83 & 9,67 & 89,50 \\
\hline Olusola and al (2018) & Nigerian & 1,87 & 1,25 & 96,88 \\
\hline Shivaprokash and al (2018) & Indian & 0 & 1,20 & 98,80 \\
\hline Degaga and al (2020)[22] & Ethiopian & 2 & 25,5 & 72,5 \\
\hline Our Study & Ivoirian & 1 & 37 & 62 \\
\hline
\end{tabular}


The Hammer and Radberg classification [15] is widely accepted because it predicts the surgical corridor used in transphenoidal surgeries. Newer and more specific classifications have also been developed which take into account the extent of sphenoid pneumatization, which facilitates extensive surgical approaches by providing natural corridors to access the base of the skull and bony recesses. [23,24]

Extension : An extension was found in $65 \%$ of cases. This frequency of extension was at the expense of the anterior clinoid process, then the large wings, followed by the clivus, small wings and the pterygoid process. In Liu's study [21] the most frequent extension was that of the small wings $(37.2 \%)$, followed by the clivus in 28 (21.4\%). Extension in anterior clinoid processes was the least represented (5\%) in Chinese. Awadalla [25], in Egypt also found a majority extension at the level of the small wing (16\%). These results diverge from those observed in the present study, in fact in Chinese and Egyptian subjects the extension of pneumatization occurs mainly at the expense of the small wings whereas it occurs at the expense of the previous clinoid process in Ivorians. . The risk of damage to the optic nerve is therefore high in Ivorian subjects.

For Hewaidi [26], protrusion of the internal carotid artery and optic nerve was strongly associated with ipsilateral pneumatization of the anterior clinoid process.

Septation and dominance : The intersinus septum was multiple in $24 \%$ with an insertion on the noble structures in $11.54 \%[25,27]$. Insertion of the septum on the walls of the $\mathrm{ACl}$ and the optic nerve should raise concerns about damage to its structures during manipulation of the septum, which should be done with caution $[16,27,28]$. The results of the present study are in agreement with Poirier [29] who found that the septum was inserted in $16 \%$ of the cases on the wall of the $\mathrm{ACl}$, Kapur [30], who found 14\%, and Cappabianca [31], which found 26\%. Elkammash [1] found that the septum was present in $86.8 \%$ of cases, it was unique and complete in $70 \%$ of cases and its insertion was done in $19.8 \%$ on the walls of the CIA (right $36.8 \%$, left $63.2 \%$ ); the septum was accessory in $8.3 \%$ with insertion on the walls of the CIA in $57.90 \%$ (right $28.6 \%$ and left $71.4 \%$ ); the septum was multiple with different orientations in $6.4 \%$ of cases. As in the Egyptian population, the dangerous insertion of the septum on the walls of a vasculo-nervous element is frequent in the Ivorian population, making the sphenoid sinus of these two populations a sinus at risk. Dominance was straight regardless of sex and type of pneumatization. These results are in agreement with those of Manisha [8] in the Indian population, who found right dominance in 20 cases and left dominance in 10 cases. As in the Indian population, the right sphenoidal sinus is larger in the Ivorian population. It provides more workspace for the surgeon.

Onodi cell: Onodi cells were frequently found (84\%) [7] and it was more common in the type of saddle pneumatization. Shin [32] found a prevalence of Onodi cells higher than previously reported (33,3\%). For him, as these cells affect sphenoid surgery, they should be removed completely to expose the edge of sellar floor and allow the complete resection of tumors located in the sellar and parasellar regions. In Kajoak's study [18] on the Sudanese population, Onodi cells were present in 13\% of patients (07 men and 06 women), 10 of them were sellaries and 03 were pre-sellaries. Onodi's cell was absent in (87\%). The results are therefore opposite, as the Onodi cell is present in most Ivorians while it is absent in most Sudanese. The presence of Onodi cells should be routinely tested by functional endoscopic surgeons to prevent damage to the optic nerve. Its prevalence makes the sphenoid sinus of the Ivorian a sinus at risk.

It is important to identify them because of their direct relationship with the optic nerve and internal carotid artery and the possibility of damaging these structures. On coronary CT images, a useful clue to the presence of these air cells is a horizontal or cruciform septum. A horizontal separation represents a downward displacement of the anterior wall of the sphenoid sinus by a superior Onodi cell and a cruciform configuration results from bilateral Onodi cells associated with a median inter sphenoidal septum [33]. Onodi cells can also 
extend into anterior clinoid processes, with pneumatization of these structures in $6 \%-13 \%$ of cases $[16,27]$. The presence of Onodi cells can cause the surgeon to become disoriented with the usual anatomy, which can be catastrophic during surgery, because behind the posterior wall of Onodi cells, the surgeon will encounter the middle cranial fossa instead of the expected sphenoidal sinus.

Frequency of vasculo-nervous structures : The incidence of vasculo-nervous elements was observed in approximately half of Ivorians (47.52\%), only in the sellary type and more frequently in men. The sphenoid sinus of the Ivorian subject is a risk sinus with a higher risk in men. The incidence of $\mathrm{ACl}$ was most often bilateral (30.00\%) and most commonly observed in males.

These results are in agreement with those of Budu [4] in Bucharest who found $34-43.6 \%$ of $\mathrm{ACl}$ procidence. This information is essential for the neurosurgeon because it will help prevent the internal carotid artery breaking out, which is a vital risk during surgery.

Optic nerve procidence appears in (16.83\%) of patients, more frequent in men and predominantly unilateral to the right. Hewaidi [26] found a high prevalence of protrusion and dehiscence of the internal carotid artery and optic nerve in lybian population. The internal carotid artery and optic nerve may not be well protected and thus could be damaged during endoscopic sphenoid surgery. In our study, as in the study of Hewaidi, the procidences of vasculo-nervous elements are only observed in sellar pneumatization. But in gender it is more important in men with a significant difference. Fuji [34], found $40 \%$ of optic nerve procidence, Elwany [35], in Egypt, found 29\% of procidence. The procidence of the optic nerve is less important in the Ivorian population than in the Egyptian population, but remains significant. Gender should be considered in sphenoid sinus procedures. The risk of break-in is greater for the internal carotid artery compared to the optic nerve.

Dehiscence of vasculo-nervous structures: In the study, the dehiscence of vasculo-nervous elements was significantly less than the procidence, it was also the case in the study Int J Anat Res 2022, 10(1):8206-15. ISSN 2321-4287 of Budu [24] which found $4 \%$ dehiscence and of Kennedy [36] which found $22 \%$; but it kept the same tendencies as the prevalence in the kind and the type of pneumatization. Dehiscence was more common in males and in the sellar type.

\section{CONCLUSION}

This study makes it possible to understand the anatomical characteristics of the sphenoidal sinus in Ivorians and thus to predict any difficulties and assess the potential risk during the transphenoidal approach.

The Ivorian sphenoid sinus is highly pneumatized, dominated by sellar-type pneumatization providing more work space for the surgeon. On the other hand, the frequency of procidence and dehiscence of vasculo-nervous elements increases the risk of surgical complications. This risk must be prevented by a good radiological study of the sinus before surgery, combined with rigorous surgery. Differences between genders and between types of pneumatization should be considered in sphenoid sinus procedures.

\section{AUTHORS' CONTRIBUTIONS}

Maman You Espérance BROALET, have made substantial contributions to conception and design, acquisition of data, analysis and interpretation of data, and have been involved in drafting the manuscript and revising it critically for important intellectual content

Dié Doweh Renaud and Kéké Jean Baptiste have made substantial contributions to conception and design, acquisition of data, analysis and interpretation of data, and have been involved in drafting the manuscript

Djibril OUATTARA and Mohamed Koné, have been involved in drafting the manuscript and revising it critically for important intellectual content;

ORCID

Maman You Espérance BROALET- https://orcid.org/00000001-5102-0974

Dié Doweh Renaud - https://orcid.org/0000-0003-47171221

Djibril Ouattara- https://orcid.org/0000-0001-8257-6377 Jean-Baptiste Kéké - https://orcid.org/0000-0002-84444236

Mohamed Koné -https://orcid.org/0000-0003-2953-5335

\section{ACKNOWLEDGEMENTS}

To Professor Haïdara, head of the department of neurochirurgie of Bouaké, and all the staff.

Conflicts of Interests: None 


\section{REFERENCES}

[1] ELkammash TH, Enaba MM, Awadalla AM. Variability in sphenoid sinus pneumatization and its impacts upon reduction complications following sellar region surgeries. The Egyptians journal of radiology and nuclear medicine 2014;45:705-714.

[2] García-Garrigós E, Arenas-Jiménez JJ, MonjasCánovas I, Abarca-Olivas J, Cortés-Vela JJ, De La HozRosa J, et al. Transsphenoidal approach in endoscopic endonasal surgery for skull base lesions: What radiologists and surgeons need to know. Radiographics. 2015;35:1170-85.

[3] Rotariu B, Costachescu Z, Faiyad R, Buga C, Santini I, Poeata N, Oblu. Difficultés et complications de la voie trans-sphénoïdale dans le traitement des adénomes hypophysaires. Neurochirurgie 2018;64(3):233.

[4] Budu V, Mogoantã CA, Fanuta B, Bulescu I. The anatomical relations of the sphenoid sinus and their implications in sphenoid endoscopic surgery, Rom J Morphol Embryol 2013 ;54(1):13-16.

[5] Learned KO, Lee JYK, Adappa ND, Palmer JN, Newman JG, Mohan S, Loevner LA, Bagley LJ. Radiologic Evaluation for Endoscopic Endonasal Skull Base Surgery Candidates. Neurographics 2015 March/April;5(2):41-55.

[6] Lupascu M, Comsa Ghl. Zainea V. Anatomical variations of the sphenoid sinus - a study of 200 cases. ARS Medica Tomitana - 2014;2(77):57-6.

[7] Lu Y, Pan J, Qi S, Shi J, Zhang X, Wu K. Pneumatization of the sphenoid sinus in Chinese: the differences from Caucasian and its application in the extended transsphenoidal approach. J. Anat. 2011;219:132-42.

[8] Manisha SC, Daksha D. A Cross-Sectional Study of Sphenoid Sinus through Gross and Endoscopic Dissection in North Karnataka, India. Journal of Clinical and Diagnostic Research. 2014;8(4):AC01AC05:1-3.

[9] Sevinc T, Esmaeili A, Chan NJ, Shukla PA, Choudhry OJ, Liu JK, Eloy JA. High-resolution computed tomography analysis of variations of the sphenoid sinus. J NeurolSurg B Skull Base 2013;74:82-90.

[10] Shivaprakash BH, Gautam AA, Sheeja K, and Geena $B$. Assessment of variations in sphenoid sinus pneumatization in Indian population: A multidetector computed tomography study. Indian J Radiol Imaging. 2018 Jul-Sep;28(3):273-9.

[11] Wiebracht ND, Zmmer LA. Complex Anatomy of the Sphenoid Sinus: A Radiographic Study and Literature Review. Journal of Neurological Surgery 2014Part B ;75(B6):378-82.

[12] Idowu OE, Balogun BO, Okoli CA. Dimensions, septation, and pattern of pneumatization of the sphenoidal sinus. Folia Morphol. 2009;68(4):228-32.

[13] Olusola C. Famurewa, Bolanle O. Ibitoye, Sanyaolu A. Ameye, Christianah M. Asaleye, Oluwagbemiga O. Ayoola, and Olaoluwa S. Onigbinde. Sphenoid Sinus Pneumatization, Septation, and the Internal
Carotid Artery: A Computed Tomography Study. Niger Med J. 2018 Jan-Feb; 59(1): 7-13.

[14] Bicaba D. Etude des variants anatomiques des sinus sphénol̈daux et de leurs rapports au scanner : à propos de 362 cas colligés dans deux $\mathrm{CHU}$ du Burkina Faso. Thèse de Médecine Institut supérieur des sciences de la Santé 2017

[15] Hammer G, Radberg C. The sphenoidal sinus: an anatomical and roentgenologic study with reference to transsphenoidhypophysectomy. ActaRadiol 1961;56(6):401-22.

[16] Sareen D, Agarwal AK, Kaul JM, Sethi A. Study of sphenoid sinus anatomy in relation to endoscopic surgery, Int J Morphol, 2005;23(3):261-6.

[17] Kim JK, et al. Sphenoid sinus pneumatization and its relation to bulging of surrounding neurovascular structures, Ann OtolRhinolLaryngol, $2010 ; 119(9)$ :646-50.

[18] Kajoak SA, Ayad CE, Balla EAA, Najmeldeen M, Yousif $M$, Musa A. Characterization of Sphenoid Sinuses for Sudanese Population Using Computed Tomography. Global Journal of Health Science 2014;6(1):135-41.

[19] Hamid O, El Fiky L, Hassan O, et al. Anatomic variations of the sphenoid sinus and their impact on trans-sphenoid pituitary surgery. Skull Base 2008;18:9-15.

[20] Banna M, Olutola P. Patterns of pneumatization and septation of the sphenoidal sinus. J Can AssocRadiol 1983;34:291-3.

[21] Liu SR, Huang L. Morphological variation of sphenoid sinus and the image on the Water's and lateral projection. Chin J Med Imaging Technol 2000;10:826-8.

[22] Degaga TK, Zenebe AM, Wirtu AT, Tequam D, Woldehawariat TD, Dellie ST, Gemechu JM. Anatomographic Variants of Sphenoid Sinus in Ethiopian Population. Diagnostics 2020;10:970.

[23] Güldner C, Pistorius SM, Diogo I, Bien S, Sesterhenn A, Werner JA. Analysis of pneumatization and neurovascular structures of the sphenoid sinus using cone-beam tomog- raphy (CBT). Acta Radiol 2012;53(2):214-9.

[24] Wang, Sharatchandra Bidari, Kohei Inoue et al. Extensions of the Sphenoid Sinus: A New Classification. Neurosurgery 2010; 66:797-816

[25] Awadalla AM., Youssef H, Tarek HE. Anatomical and Radiological Parameters of the Sphenoid Sinus among Egyptians and its Impact on Sellar Region Surgery. Egyptian Journal of Neurosurgery 2015;30(1):1-12.

[26] Hewaidi GH, Omami GM. Anatomical variation of sphenoid sinus and related structures in Libyan population: CT scan study. Libyan J Med. 2008;3:128-33.

[27] Wang SS, Xue L, Jing JJ, Wang RM. Virtual reality surgical anatomy of the sphenoid sinus and adjacent structures by the transnasal approach. Journal of Cranio-Maxillofacial Surgery, 2012; 40: 494-9. 
[28] Gardner PA, Kassam AB, Snyderman CH, et al. Outcome $s$ following endoscopic extended endonasal resection of suprasellarcraniopharyngiomas: a case series. J Neurosurgery, 2008; 109(1):6-16.

[29] Poirier J, Duggal N, Lee D, Rotenberg B. Sphenoid sinus septation: unpredictable anatomic landmarks in endoscopic pituitary surgey. Journal of Otolaryngology, Head and Neck Surgery 2011; 40(6): 48992.

[30] Kapur E, Kapidzic A, Kulenovic A, et al. Septation of the sphenoid sinus and its clinical significance. International Journal of Collaboration Research on Internal Medicine and Public Health 2012;4(10):1793-1802.

[31] Cappabianca P, Cavallo, LM, Esposito F, et al. Endoscopic transsphenoidal surgery: anatomy, instrumentation, techniques, in: transsphenoidal surgery. Laws Jr ER, Lanzino G, editors, Elsevier Saunders, Philadilphia 2010;128-42.
[32] Shin JM, Jang WI, Baek BJ. Analysis of Sphenoid Sinus and Surrounding Structures Using Multidetector Computed Tomography. KJORL 2012;55:95-100.

[33] Cappabianca P, Cavallo, LM, Esposito F, et al. Endoscopic endonasale transsphénoïdal surgery in recurrent and residual pituitary adenomas technical note. Minim invasive Neurosurg. 2000;45(1):5843.

[34] Fuji K, Chambers A, Rhoton J. Neurosurgical relationships of the sphenoid sinus: a microsurgical study. J. Neurosurgery. 1979;50:31-9.

[35] Elwany.S, Elsaeid I,Thabet H. Endoscopic anatomy of the sphenoid sinus. The Journal of Laryngology and Otology. February 1999;113: 122-6.

[36] Kennedy D, Zinrich H, Hassab M. The internal carotid artery as it relates to endoscopic sphenoethmoidectomy. Am J Rhinology 1990;4:7-12.

How to cite this article:

Maman You Espérance BROALET, Dié Doweh Renaud, Djibril Ouattara, JeanBaptiste Kéké , Mohamed Koné. Radioanatomical Features of the Sphenoid Sinus in the Ivorian Population. Int J Anat Res 2022;10(1):8206-8215. DOI: 10.16965/ijar.2021.187 